\title{
Peningkatan Hasil Belajar Materi Penjumlahan Pecahan dengan Pendekatan Konstruktivisme
}

\author{
*Taufiqur Rohman ${ }^{1}$, Paramita Ayu Ekasari² \\ ${ }^{1,2}$ Pascasarjana IAIN Salatiga, Jawa Tengah, Indonesia
}

\begin{abstract}
:
The study aimed to answer how the Constructivism approach can improve students' learning outcomes of adding fraction material in fourth-grade students of Madrasah Ibtidayah Tukangan, Ampel District, Boyolali Regency, Academic Year 2015/2016. This Classroom Action Research was carried out in two cycles. Each cycle has four stages, namely planning, implementing, observing, and reflecting. The data collection methods used were post-test observation sheets and documentation. The findings of this study revealed that the implementation of the Constructivism Approach can improve students' mathematics learning outcomes in adding fractions. This increase occurred from the first, and second cycles with the results of the Pre-test and Post-test have increased. In the first cycle, the mean score of the pre-test was 61.67, while the post-test was 68.88 . In the second cycle, the mean score of the pre-test was 75 , and the post-test was 88.89 . Therefore, the mean score of pre-test, and post-test was increased by 13.89 or $22.23 \%$. The increase of the mean score on the Pre-test and Post-test showed that the Constructivism approach can improve student learning outcomes.
\end{abstract}

Keywords: Learning outcomes, Constructivism, Mathematics

\section{Abstrak:}

Masalah utama yang ingin dijawab dalam penelitian ini adalah: Apakah penerapan pendekatan Konstruktivisme mampu meningkatakan hasil belajar siswa terhadap materi penjumlahan pecahan pada siswa kelas IV Madrasah Ibtidayah Tukangan Kecamatan Ampel Kabupaten Boyolali Tahun Pelajaran 2015/2016. Penelitian tindakan kelas ini dilaksanakan melalui dua siklus. Tiap siklusnya ada empat tahapan yaitu perencanaan, pelaksanaan, pengamatan, dan refleksi. Adapun metode pengumpulan data yang digunakan meliputi post tes lembar pengamatan dan dokumentasi. Temuan dari penelitian ini menunjukkan bahwa penerapan Pendekatan Konstruktivisme dapat meningkatkan hasil belajar Matematika materi Penjumlahan Pecahan. Peningkatan tersebut dapat dilihat dari siklus I dan II dengan hasil Pre tes dan Post tes mengalami peningkatan. Pada siklus I rata-rata Pre tes adalah 61,67 dengan dan rata- rata Post tes 68, 88. Dari rata-rata Pre tes dan Pos tes mengalami peningkatan 7,21 dengan persentase peningkatan 16,67 \%. Pada siklus II rata-rata Pre tes adalah 75 dan rata-rata Post tes 88,89. Dari rata-rata Pre tes dan Pos tes mengalami peningkatan13,89 dengan persentase peningkatan sebesar 22, 23\%. Peningkatan nilai rata-rata pada Pre tes dan Post tes menunjukkan pendekatan Konstruktivisme dapat meningkatkan hasil belajar siswa.

Kata Kunci: Hasil belajar, Pendekatan Konstruktivisme, Matematika.

\section{Cara mensitasi artikel ini:}

Rohman, T., \& Ekasari, P. A. (2021). Peningkatan hasil belajar materi penjumlahan pecahan dengan pendekatan konstruktivisme. Mitra PGMI: Jurnal Kependidikan MI, 7(1), 1-9. https://doi.org/10.46963/mpgmi.v7i1.211.

\section{INFORMASI ARTIKEL}

\section{*Corresponding author:} rohmantaufiqur93@gmail.com

DOI:

https://doi.org/10.46963/mpgmi.v7i1.211

\section{Histori Artikel:}

$\begin{array}{ll}\text { Diterima } & : 03 / 11 / 2020 \\ \text { Direvisi } & : 22 / 12 / 2020 \\ \text { Diterbitkan } & : 25 / 01 / 2021\end{array}$

\section{PENDAHULUAN}

Matematika merupakan salah satu mata pelajaran pokok dalam kurikulum pendidikan di Indonesia, termasuk pada jenjang sekolah dasar. Matematika merupakan 
mata pelajaran yang selama ini dianggap sulit oleh sebagian besar peserta didik (Yulita, 2020). Mulai dari jenjang sekolah dasar sampai sekolah menengah.Anggapan sebagian besar peserta didik yang menyatakan bahwa pelajaran Matematika ini sulit adalah benar terbukti dari hasil perolehan Ujian Akhir Sekolah (UAS) masih sangat jauh dari standar yang diharapkan. Salah satu masalah yang dihadapi dunia pendidikan saat ini adalah masalah lemahnya pelaksanaan proses pembelajaran yang diterapkan para guru di sekolah. Proses pembelajaran yang terjadi selama ini kurang mampu mengembangkan kemampuan berpikir peserta didik. Pelaksanaan proses pembelajaran yang berlangsung di kelas hanya diarahkan pada kemampuan siswa untuk menghafal informasi, otak siswa dipaksa hanya untuk mengingat dan menimbun berbagai informasi tanpa dituntut untuk memahami informasi yang diperoleh untuk menghubungkannya dengan situasi dalam kehidupan sehari-hari (Sriyanti, 2013).

Kondisi ini juga terjadi pada pembelajaran Matematika, yang memperlihatkan bahwa selama ini proses pembelajaran Matematika di sekolah dasar masih banyak yang dilaksanakan secara konvensional. Para guru belum sepenuhnya melaksanakan pembelajaran secara aktif dan kreatif dalam melibatkan siswa serta belum menggunakan berbagai pendekatan pembelajaran yang bervariasi berdasarkan karakter materi pelajaran (Sriyanti \& Suwardi, 2009). Penyebab utama kelemahan pembelajaran tersebut adalah karena kebanyakan guru tidak melakukan kegiatan pembelajaran dengan memfokuskan pada pengembangan keterampilan proses pada anak (Nurlianti \& Napratilora, 2020). Selain itu guru masih menggunakan pendekatan konvensional dalam menyampaikan materi. Siswa diberikan definisi-definisi maupun teorema-teorema, setelah itu langsung diberi contoh-contoh sehingga peserta didik hanya memperoleh catatan yang berupa simbol-simbol dan rumus-rumusnya saja tidak ada aplikasinya dalam kehidupan seharihari. Hal ini berakibat pada siswa yang apabila mereka diberi soal yang berbeda dengan contoh-contoh atau soal latihan cenderung membuat kesalahan. Selain itu rendahnya minat belajar matematika dengan materi dan metode yang kurang menarik. Dengan keadaan yang seperti tersebut di atas menyebabkan rendahnya hasil belajar Matematika.

Oleh karena itu dapat dikatakan bahwasanya belajar merupakan suatu kegiatan yang penting untuk dilaksanakan. Pada akhirnya, keadaan semacam ini yang menyebabkan kegiatan pembelajaran dilakukan hanya terpusat pada penyampaian materi dalam buku teks saja. Keadaan seperti ini juga mendorong siswa untuk berusaha menghafal pada setiap kali akan diadakan tes atau ulangan harian atau tes hasil belajar, baik ulangan tengah semester, maupun ulangan akhir semester. Peranan penggunaan pendekatan pembelajaran di kelas apabila dilihat dari kenyataan di lapangan banyak sekali dijumpai sekolahan-sekolahan yang belum menggunakan pendekatan pembelajaran dalam pengajarannya di dalam kelas secara maksimal dan kurang bervariasi. Melihat keadaan yang seperti itu maka dapat dianalisis kekurangan dalam proses pembelajaran guna mengetahui kendala-kendala dan hambatan yang ditemukan untuk perbaikan yang lebih baik dalam proses pembelajaran yang berikutnya. Guru harus berpikir kritis proses pembelajaran yang dirancang sedemikian rupa agar siswa secara aktif mengonstruksi konsep (Liana, 2020).

Print - ISSN: $2443-0021$
Online - ISSN: $2716-4136$ 
Dalam melakukan perbaikan proses pembelajaran dilakukan penelitian tindakan kelas untuk meningkatkan hasil belajar siswa. MI Tukangan adalah salah satu MI yang ada di Kecamatan Ampel.MI ini telah menerapkan Kurikulum Tingkat Satuan Pelajaran (KTSP), namun menurut hasil wawancara dengan guru diketahui bahwa terdapat beberapa kendala dalam pelaksanaan KTSP. Salah satu kendala utama adalah kurangnya antusias siswa untuk belajar, siswa lebih cenderung menerima apa saja yang disampaikan oleh guru, diam dan enggan dalam mengemukakan pertanyaan maupun pendapat. Berdasarkan informasi tersebut, dilakukan observasi di MI Tukangan pada tanggal April dan diperoleh keterangan bahwa hasil belajar Matematika siswa kelas IV di madrasah tersebut masih tergolong rendah. Hal ini dapat dilihat dari kriteria ketuntasan minimal yang diterapkan untuk mata pelajaran Matematika adalah65 . Dari hasil survei pada bulan April diketahui bahwa dari sejumlah 18 siswa, 6 siswa memperoleh nilai KKM dan 12 siswa yang lain belum memenuhi KKM yang ditentukan.

Dari hasil wawancara ini pula diperoleh informasi dari guru pengampu Matematika kelas IV bahwa siswa sering kali mengalami kesulitan dan kekeliruan dalam menyelesaikan soal-soal latihan. Peneliti dan guru menduga pendekatan pembelajaran yang digunakan selama ini belum efektif. Hal inilah yang menyebabkan rendahnya hasil belajar Matematika siswa kelas IV MI Tukangan. Atas dugaan di atas maka peneliti bersama-sama dengan guru sepakat untuk mencobakan suatu tindakan alternatif untuk mengatasi masalah yang ada berupa penerapan pendekatan pembelajaran lain yang lebih mengutamakan keaktifan siswa dan memberi kesempatan siswa untuk mengembangkan potensinya secara maksimal.

Pendekatan pembelajaran yang dimaksud adalah pendekatan pembelajaran Konstruktivisme (Martinis, 2008). Penjumlahan pecahan dalam kehidupan sehari-hari merupakan materi yang di dalamnya memerlukan pemahaman dari sisi konsep. Pecahan merupakan salah satu topik yang sulit diajarkan, Kesulitan itu terlihat dari kurang bermaknanya kegiatan pembelajaran yang dilakukan oleh guru (Heruman, 2007). Sehingga siswa memerlukan cara yang tepat untuk memahaminya. Namun berdasarkan fakta yang penulis temukan di lapangan, MI Tukangan dalam penggunaan pendekatan yang variatif masih belum digunakan. Proses KBM di sekolah tersebut masih sangat monoton yang menjadikan salah satu faktor belum tercapainya hasil belajar yang maksimal.

Terkait dengan penelitian yang relevan peneliti melihat dari penelitian terdahulu dengan judul Penerapan pembelajaran dengan model konstruktivisme berbantuan concept map pada materi stoikiometri dapat meningkatkan hasil belajar siswa kelas X-3 di sebuah SMA di Kabupaten Brebes dari siklus I, siklus II, dan siklus III. Mengalami peningkatan yang sangat drastis dengan model konstruktivisme (Novia \& Kusumo, 2013). Penelitian selanjutnya yang berjudul Peningkatan Hasil Belajar Siswa Melalui Pembelajaran Konstruktivistik Pada Materi Sistem Gerak Di SMKN 13 Kota Malang (Chotimah, 2018). Hasil belajar siswa menunjukkan kemajuan yang signifikan dilihat dari model 
pembelajaran konstrukvistik dengan penelitian tersebut penulis tertarik untuk menggali lebih lanjut dengan melakukan penelitian dengan pendekatan konstruktivisme.

Membangun pengetahuan merupakan cara belajar yang mengembangkan proses belajar bermakna, yang akan meningkatkan pemahaman siswa dan daya ingat belajarnya. Melalui pendekatan Konstruktivisme siswa dapat meningkatkan keaktifan dan kreativitas berpikir, hal ini menimbulkan sikap kemandirian belajar yang lebih pada siswa.

\section{METODE PENELITIAN}

Penelitian yang dilakukan menggunakan penelitian tindakan kelas, istilah dalam bahasa inggrisnya adalah Classroom Action Research (CAR). Penelitian tindakan kelas adalah penelitian tindakan dalam bidang pendidikan yang dilaksanakan dalam kawasan kelas dengan tujuan untuk memperbaiki dan atau meningkatkan kualitas pembelajaran. Alasan peneliti menggunakan penelitian tindakan kelas, agar permasalahan-permasalahan dalam pembelajaran di dalam kelas dapat dipecahkan.

Penelitian ini dilaksanakan di MI Tukangan Kabupaten Boyolali dan dilaksanakan di kelas IV yang berjumlah 18 siswa. Terdiri dari 8 siswa laki-laki dan 12 siswi perempuan. Arikunto mengemukakan bahwa tahap-tahap dalam Penelitian Tindakan Kelas (PTK) terdiri dari empat tahapan penting, meliputi: (1) Planning (rencana), (2) Action (tindakan), (3) Observation (pengamatan) dan (4) Reflection (refleksi) (Suharsimi, 2006). Dalam pengumpulan data penelitian ini cara mengumpulkan data dengan menggunakan metode Pengamatan atau Observasi dan wawancara. Pengamatan adalah suatu pengamatan langsung terhadap peserta didik dengan memperhatikan tingkah lakunya secara teliti.

Dalam setiap siklus guru melakukan pengamatan kepada siswa untuk mengetahui sejauh mana perhatian aktivitas, dan hasil belajar terhadap materi Matematika yang diajarkan. Wawancara digunakan untuk mendapatkan informasi tentang karakteristik siswa secara umum, tingkat hasil belajar siswa terhadap mata pelajaran khususnya Matematika. Analisis data sangat diperlukan guna mengetahui hasil dan atau untuk menarik kesimpulan yang logis berdasarkan data-data yang telah dikumpulkan di setiap siklusnya.

Untuk menilai rata-rata ulangan tes formatif digunakan penghitungan dengan rumus (Dzamarah, 2010):

$$
\begin{aligned}
& \mathrm{M}=\frac{\sum X}{N} \\
& \text { Keterangan: } \\
& \mathrm{M} \quad=\text { Nilai rata-rata } \\
& \sum \mathrm{X}=\text { Jumlah semua nilai kelas } \\
& \mathrm{N} \quad=\text { Jumlah siswa }
\end{aligned}
$$

Untuk menghitung prosentase ketuntasan belajar siswa digunakan rumus (Dzamarah, 2010). 
Taufiqur Rohman dan Paramita Ayu Ekasari

Peningkatan Hasil Belajar Materi Penjumlahan Pecahan ....

$$
\begin{aligned}
& \mathrm{P}=\frac{F}{N} \times 100 \% \\
& \text { Keterangan: } \\
& \mathrm{P} \quad=\text { Jumlah nilai dalam persen } \\
& \mathrm{F} \quad=\text { Frekuensi } \\
& \mathrm{N} \quad=\text { Jumlah nilai keseluruhan }
\end{aligned}
$$

\section{HASIL DAN PEMBAHASAN}

Dalam bagian ini disajikan hasil penelitian dan pembahasan sesuai dengan tujuan penelitian yaitu untuk mengetahui bahwa pendekatan Kontruktivisme dapat meningkatkan hasil belajar siswa pada mata pelajaran Matematika materi Penjumlahan pecahan pada kelas IV di MI Tukangan Kabupaten Boyolali Tahun Pelajaran 2015/2016.

\section{Hasil Penelitian}

Pendekatan yang digunakan pada pembelajaran Matematika di MI Tukangan sebelum diterapkannya pendekatan Konstruktivisme adalah Pendekatan Konvensional yang sering digunakan, sehingga pemahaman siswa kurang dalam proses pembelajaran ("Seputar Kuliah Matematika: Hasil Penelusuran Untuk Kelebihan Dan Kelemahan Pendekatan Konstruktivisme," n.d.). Dari hasil prasiklus diperoleh nilai murni siswa pada mata pelajaran Matematika sebagai pembanding antara sebelum dan sesudah diterapkannya pendekatan Konstruktivisme. Adapun nilai Ketuntasan Kriteria Minimum (KKM) kelas IV MI Tukangan pada mata pelajaran Matematika yaitu 65.

\section{Siklus I}

Pada siklus I peneliti telah menerapkan pembelajaran dengan menggunakan Pendekatan Konstruktivisme untuk mata pelajaran Matematika kelas IV materi Penjumlahan Pecahan.

\section{a. Data Hasil Pengamatan}

Nilai Siswa siklus 1 dengan jumlah siswa 18 diperoleh hasil nilai dengan nilai rata rata pre test yaitu 61,67 kemudian dipersentasekan dari hasil pre test siklus I dengan total nilai persentase pre test siklus I yaitu 33,33\% . Dari hasil nilai presentase pre test I tersebut dilakukan post test dengan nilai rata rata post test I dengan total nilai 68,88 dengan nilai persentase post test siklus I $50 \%$.

Dari data nilai Siklus I di atas dapat disimpulkan bahwa pada nilai post test siswa telah meningkat jika dibandingkan dengan pre test. Siswa yang tuntas pada saat pre test sebanyak 6 siswa atau 33,33\%, sedangkan siswa yang tuntas pada saat post test sebanyak 9 siswa atau $50 \%$ meningkat 3 siswa atau 16,67\%, jika dibandingkan saat pre test. Nilai rata-rata pada post test adalah 68,88 atau 50\% naik dari nilai rata-rata kelas saat pre test yang hanya 61, 67 atau 33,33\%.

\section{b. Refleksi}

Tahap akhir dari siklus pertama ini, peneliti dapat menemukan beberapa keberhasilan yang dicapai, diantaranya: 
1) Sebagian besar siswa mendengarkan dan memperhatikan penjelasan guru.

2) Sebagian siswa telah aktif mengikuti proses pembelajaran yang berlangsung.

3) Sebagian siswa sudah dapat menjawab soal-soal yang diberikan peneliti.

Meskipun sudah ada beberapa keberhasilan dalam pembelajaran, namun masih ada banyak kekurangan dalam pembelajaran tersebut, diantaranya:

1) Dalam pembelajaran masih ada beberapa siswa yang kurang aktif dan mengabaikan materi pelajaran karena siswa mengalami kesulitan dalam pembelajaran sehingga mengakibatkan sebagian siswa kurang memahami soal dalam menjawab pertanyaan.

2) Penggunaan waktu kurang efektif.

3) Keberanian siswa untuk bertanya dan menjawab pertanyaan masih kurang.

Untuk mengatasi kekurangan pada siklus I peneliti melakukan ide perbaikan. Hal ini dilakukan supaya pada siklus berikutnya tidak terjadi kekurangan yang sama.

1) Guru lebih terampil dalam mengelola kondisi siswa pada saat pembelajaran.

2) Guru mengelola waktu secara baik sehingga waktu lebih efektif dan efisien.

3) Memotivasi siswa agar lebih aktif di dalam kelas.

Untuk mengatasi kekurangan pada siklus I peneliti melakukan ide perbaikan. Hal ini dilakukan supaya pada siklus berikutnya tidak terjadi kekurangan yang sama.

1) Guru lebih terampil dalam mengelola kondisi siswa pada saat pembelajaran.

2) Guru mengelola waktu secara baik sehingga waktu lebih efektif dan efisien.

3) Memotivasi siswa agar lebih aktif di dalam kelas.

\section{Siklus II}

Pada siklus ini selain memaksimalkan penerapan penggunaan pendekatan Kontruktivisme peneliti juga mencoba mengatasi kekurangan pada siklus sebelumnya dengan memancing siswa untuk aktif dan menyediakan beberapa media agar suasana dalam kelompok menjadi menyenangkan.

\section{a. Data Hasil Pengamatan}

Hasil pengamatan menunjukkan bahwa siswa mengikuti proses pembelajaran dengan baik dan jauh lebih meningkat. Nilai rata-rata kelas mengalami peningkatan yaitu dari 75 atau 66, 66\% menjadi 88, 89 atau 88, $89 \%$. Ada juga siswa yang mendapat nilai 100 . Peningkatan ketuntasan nilai pada siklus II sebanyak 4 siswa atau 22, 23\%, yaitu siswa yang tuntas pada saat pre test sebanyak 12 siswa sedangkan siswa yang tuntas pada saat post test sebanyak 16siswa. Namun, masih ada siswa yang belum bisa tuntas nilai KKM 65 yaitu 2 siswa. 
Hasil pembelajaran ini sudah memenuhi standar ideal ketuntasan belajar karena sudah mencapai nilai rata-rata 88, 89 atau 88, 89\%.Adapun 2 siswa yang belum tuntas, menurut pengamatan guru memang menglami gangguan penglihatan, kurang memiliki motivasi untuk belajar, dalam mengikuti pembelajaran, dan kurang aktif pada saat pembelajaran berlangsung.

\section{b. Refleksi}

Berdasarkan lembar hasil peneliti yang diperoleh, nilai pada siklus II lebih meningkat jika dibandingkan dengan siklus I. pada siklus II ini hanya dua siswa yang belum dapat mencapai ketuntasan KKM, Hal ini disebabkan bahwa siswa tersebut mengalami gangguan penglihatan. Refleksi pada siklus II didapatkan satu pendekatan pembelajaran untuk mata pelajaran Matematika karena semua siswa dapat mengikuti pembelajaran dengan baik dan mendapatkan hasil yang baik.Penelitian pada siklus I dan siklus II telah cukup untuk memperlihatkan adanya peningkatan hasil belajar, sehingga peneliti tidak perlu melanjutkan ke siklus berikutnya.Pada siklus II ini, peneliti telah berhasil dalam meningkatkan hasil belajar Matematika melalui pendekatan Konstruktivisme pada siswa kelas IV MI Tukangan Kecamatan Ampel Kabupaten Boyolali.

\section{Pembahasan Hasil Penelitian}

Dari paparan hasil penelitian dari siklus I dan Siklus II diperoleh data nilai hasil belajar keseluruhan sebagai berikut:

Tabel 1. Data Peningkatan Jumlah Siswa yang Mencapai KKM per Siklus

\begin{tabular}{llll} 
Kegiatan & Pre Test & Post Test & Peningkatan \\
\hline Siklus I & 6 Siswa atau 33,33\% & 9 Siswa atau 50\% & 3 Siswa atau, 16, 67\% \\
Siklus II & 12 Siswa atau 66, 66\% & 16 Siswa atau 88, 89\% & 5 Siswa atau 22, 23\%
\end{tabular}

Berdasarkan data di atas dapat diketahui bahwa siklus I peningkatan siswa yang tuntas dari pre test ke post test sebanyak 3 siswa atau 16, 67\%, dan pada siklus II peningkatan dari pre test ke post test sebanyak 4 siswa atau 22, 23\%. Dari hasil tersebut dapat disimpulkan bahwa mulai dari siklus I sampai siklus II siswa mengalami peningkatan yang cukup baik. Hasil belajar siswa ini dipengaruhi karena motivasi belajar siswa yang sangat tinggi pada mata pelajaran Matematika dengan menggunakan Pendekatan Konstruktivisme, adapun faktor lain yang mempengaruhi tingkat keberhasilan siswa adalah faktor bakat, minat, tingkat intelegensi, karakteristik belajar anak, strategi, metode, dan media yang digunakan guru dalam pembelajaran. 
Mitra PGMI: Jurnal Kependidikan MI

Vol. 07 No. 01 Tahun 2021

\section{KESIMPULAN DAN SARAN}

Berdasarkan hasil penelitian yang telah dilakukan, maka dapat disimpulkan bahwa penerapan Pendekatan Konstruktivisme pada mata pelajaran Matematika materi Penjumlahan pecahan dapat meningkatkan hasil belajar siswa kelas IV di MI Tukangan Kabupaten Boyolali. Hal ini dapat dibuktikan dengan adanya peningkatan dari siklus I ke siklus II. Pada siklus I ini nilai yang tuntas sesuai KKM sebanyak 9 siswa atau $50 \%$. Sedangkan pada siklus II nilai yang tuntas sebanyak 16 siswa atau 88, 89\% dan nilai ratarata yang diperoleh 88,89 .

Berdasarkan penelitian yang telah dilakukan, penulis memberikan saran sebagai berikut:

Bagi Guru, Guru sebagai mediator dan motivator bagi siswa, sangatlah mempengaruhi kemajuan siswa yang dibawanya. Oleh sebab itu, sebagai guru hendaknya memiliki sikap aktif dan kreatif agar mampu mengolah pembelajaran menjadi hal baru setiap harinya dengan mengembangkan berbagai pendekatan, strategi, metode, maupun model pembelajaran.

Bagi Sekolah, Setiap sekolah selalu menginginkan seluruh siswanya menjadi anakanak yang sukses dan dapat mengharumkan nama sekolahnya. Untuk mencapai keinginan tersebut, maka sekolah hendaknya memberi dukungan bagi tenaga pendidik yaitu guru untuk memberikan fasilitas yang memadai, seperti menyediakan media, alat peraga, dan sumber belajar yang cukup untuk siswa-siswanya.

\section{REFERENSI}

Arikunto, Suharsimi. (2010). Prosedur Penelitian Suatu Pendekatan Praktik. Jakarta: Rineka Cipta.

Chotimah, H. (2018). Peningkatan Hasil Belajar Siswa Melalui Pembelajaran Konstruktivistik Pada Materi Sistem Gerak di SMKN 13 Kota Malang. Pionir, 1(1), 44-50. http://dx.doi.org/10.33477/bs.v2i1.145.

Dzamarah, S. B. (2010). Guru dan Anak Didik dalam Interaksi Edukatif; Suatu Pendekatan Teoritis Psikologis. Jakarta: PT. Rineka Cipta.

Heruman.(2010). Model Pembelajaran Matematika di Sekolah Dasar. Bandung. PT Remaja Rosdakarya.

Liana, D. (2020). Berpikir Kritis Melalui Pendekatan Saintifik. Mitra PGMI: Jurnal Kependidikan MI, 6(1), 15-27. https://doi.org/10.46963/mpgmi.v6i1.92.

Martinis, Y. (2008). Paradigma Pendidikan Konstruktivistik. Jakarta: Gaung Persada.

Novia, T. R., \& Kusumo, E. (2013). Penerapan Model Pembelajaran Konstruktivisme Berbantuan Concept Map Untuk Meningkatkan Hasil Belajar Kimia Pada Siswa SMA. Jurnal Inovasi Pendidikan Kimia, 7(1). 
Taufiqur Rohman dan Paramita Ayu Ekasari Peningkatan Hasil Belajar Materi Penjumlahan Pecahan ....

Nurlianti, N., \& Napratilora, M. (2020). Pelaksanaan Metode Pembelajaran Picture And Picture Oleh Guru Fikih Di Madrasah Ibtidaiyah Al-Rasyid Simpang Tiga Sungai Luar Kecamatan Batang Tuaka. Mitra PGMI: Jurnal Kependidikan MI, 6(1), 3849. https://doi.org/10.46963/mpgmi.v6i1.94.

Seputar Kuliah Matematika: Hasil penelusuran untuk Kelebihan dan Kelemahan Pendekatan Konstruktivisme. (n.d.). Retrieved January 21, 2021, from https://yunihandayani97.blogspot.com/search?q=Kelebihan+dan+Kelemahan+Pe ndekatan+Konstruktivisme

Sriyanti, L. (2013). Psikologi belajar. Yogyakarta: Ombak, 187.

Sriyanti, L., \& Suwardi, M. E. (2009). Teori-teori belajar. STAIN Salatiga Pres.

Yulita, E. (2020). Penerapan Pendekatan Realistic Mathematics Education Untuk Meningkatkan Hasil Belajar Matematika Pada Siswa Kelas III.B Madrasah Ibtidaiyah Negeri Tembilahan Kecamatan Tembilahan. Mitra PGMI: Jurnal Kependidikan MI, 6(1), 1-14. https://doi.org/10.46963/mpgmi.v6i1.91. 